Viçosa, MG, DEA/UFV - DOI: 10.13083/reveng.v29i1.11123

v.29, p.263-274, 2021

\title{
PASSION FRUIT PRODUCTION UNDER DIFFERENT SWINE WASTEWATER DOSES TREATED IN A BIODIGESTER
}

\author{
Manuel Antonio Navarro Vásquez*1 (D), Ana Maria Sousa Santos ${ }^{1}$ (D), Danilo Francisco de Oliveira1 (iD), Edilza Maria Felipe \\ Vásquez $^{2}$ (D), Francisco Gauberto Barros dos $\operatorname{Santos}^{1}$ (D) \& Francisco Rondynelle Rodrigues Sousa ${ }^{1}$ (id \\ 1 - Institute of Education, Science and Technology of Ceará, Crato campus, Crato, Ceará, Brazil \\ 2 - Federal University of Cariri, Faculty of Agronomy, Center for Agricultural Sciences and Biodiversity, Crato, Ceará, Brazil
}

\begin{abstract}
Keywords:
Biofertilizer

Organic agriculture

Soil quality

Fruticulture

ABSTRACT

Soil fertilization using materials of animal origin, such as biofertilizers, is an important practice to maintain productive soil, as they provide beneficial effects on soil physical, chemical, and biological properties. This study aimed to evaluate the number of fruits, fruit mass, and yield of yellow passion fruits in the first year of cultivation with the application of swine wastewater (SW) treated in a biodigester. The experiment was set up at the experimental area belonging to IFCE Crato, CE, Brazil, with a spacing of $5.0 \mathrm{~m}$ between plants and $3.0 \mathrm{~m}$ between rows, using the espalier system of training and drip irrigation. The experiment was conducted in a randomized block design, with five treatments and four replications. Treatments consisted of five SW doses $\left(\mathrm{D}_{1}=0, \mathrm{D}_{2}=0.50, \mathrm{D}_{3}=1.00, \mathrm{D}_{4}=1.50\right.$, and $\left.\mathrm{D}_{5}=2.00 \mathrm{~L} \mathrm{plant}^{-1}\right)$ applied at two phenological stages of the crop. The results were subjected to analysis of variance at a $5 \%$ significance, followed by the regression test. The increased SW doses influenced all the studied variables, following the linear and quadratic regression models, except for the mean fresh fruit mass. The highest yield was achieved with the highest studied dose, being an interesting alternative for recommendation to farmers in the region.
\end{abstract}

Palavras-chave:

Biofertilizante

Agricultura orgânica

Qualidade do solo

Fruticultura
PRODUÇÃO DE MARACUJAZEIRO SOB DIFERENTES DOSES DE ÁGUA RESIDUÁRIA DE SUINOCULTURA TRATADA EM BIODIGESTOR

\section{RESUMO}

A fertilização dos solos com materiais de origem animal, como os biofertilizantes, apresenta-se como uma importante prática para manter o solo produtivo, pois exerce efeitos benéficos sobre as suas propriedades físicas, químicas e biológicas. Objetivou-se com este trabalho avaliar o número, a massa de frutos e a produtividade do maracujazeiro amarelo azedo, no primeiro ano do cultivo, com aplicação de água residuária da suinocultura tratada em biodigestor (ARS). O experimento foi instalado na área experimental do IFCE Crato, CE, Brasil, o espaçamento utilizado foi de 5,0 m entre plantas e 3,0 m entre linhas, no sistema de condução em espaldeira mediante irrigação por gotejamento. $\mathrm{O}$ experimento foi conduzido no delineamento em blocos casualizados, com cinco tratamentos e quatro repetições. Os tratamentos consistiram em cinco doses de ARS $\left(\mathrm{D}_{1}=0 ; \mathrm{D}_{2}=0,50 ; \mathrm{D}_{3}=1,00 ; \mathrm{D}_{4}=1,50\right.$ e $\left.\mathrm{D}_{5}=2,00 \mathrm{~L}_{\text {planta }}{ }^{-1}\right)$ aplicados em duas etapas fenológicas da cultura. Os resultados foram submetidos à análise de variância a 5\% de significância e após efetuou-se o teste de regressão. Foi observado que o incremento das doses de ARS influencia todas as variáveis estudadas, seguindo modelos de regressão linear e quadrática, exceto, para a massa fresca média dos frutos. A maior produção foi alcançada com a maior dose estudada, sendo uma alternativa interessante para recomendação aos agricultores da região. 


\section{INTRODUCTION}

The center of origin of passion fruit is Tropical America, with more than 150 species native to Brazil. Yellow passion fruit (Passiflora edulis Sims f. flavicarpa Deg.) is the most important commercial species, representing $95 \%$ of the orchards in Brazil and the most planted in the world (BERNACCI et al., 2008; MELETTI et al., 2011). Brazil is the center of origin of several species of the family Passifloraceae and the largest producer of this fruit since the 1990s, being a crop of great economic importance (RODOLFO JUNIOR et al., 2009).

Swine manure has a high nutrient concentration and may contaminate the soil and watercourses when improperly disposed of in the environment, leading to environmental impacts (ARAÚJO et al., 2012; SCHERER et al., 2010). Thus, considering the risks of environmental pollution, many production units have started to store wastewater in tanks for subsequent release to the soil in different crops (MENEZES et al., 2017; SOUZA et al., 2009).

The use of swine wastewater (SW) as a soil fertilizer has been based on economic aspects and sustainability of agricultural production systems, as it represents an internal resource of farmers and contains nutrients and organic matter with the potential to improve crop yield, being essential an adequate treatment and management (PEREIRA et al., 2010).

The importance of SW going through the biodigester first implies the mineralization of the organic matter of common biofertilizers, being a process that requires a certain amount of time, as the speed at which mineralization occurs depends mainly on the chemical composition of organic matter (MARROCOS et al., 2012; TEJADA et al., 2016). Thus, humic substances interact with manure compounds and, consequently, provide readily available nutrients for plant nutrition.

Considering SW characteristics, its application can contribute to improving soil physical and chemical attributes, reducing environmental pollution, and improving the quality of agricultural products (DAROS et al., 2017). Mellek et al. (2010) observed that SW has advantages to improving soil physical conditions through aeration and porous space of the root system of plants. Similarly, Singh et al. (2011) reported improved fertility by increasing the population and diversification of soil microorganisms.

Moraes et al. (2014) and Alves Neto et al. (2016) obtained maximum corn yields of 10.05 , 12.88 , and $6.24 \mathrm{Mg} \mathrm{ha}^{-1}$ with SW applications of $143,91.83$, and $140 \mathrm{~m}^{3} \mathrm{ha}^{-1}$, respectively. Also, Lima et al. (2019) reported a linear response of up to $100 \mathrm{~m}^{3} \mathrm{ha}^{-1}$ of SW, with an increasing dose.

Reis et al. (2018) demonstrated significant differences in the mean yield between different passion fruit cultivars at the end of six months of harvest with the topdressing SW application at a dose of two liters per plant.

Similarly, Alves Neto et al. (2016) reported an increase of $124.81 \mathrm{~kg} \mathrm{ha}^{-1}$ in soybean yield compared to the control up to the dose of $105 \mathrm{~m}^{3}$ $\mathrm{ha}^{-1}$ year ${ }^{-1}$, but the dose of $140 \mathrm{~m}^{3} \mathrm{ha}^{-1}$ showed a yield reduction trend of $50.58 \mathrm{~kg} \mathrm{ha}^{-1}$ compared to the dose of $105 \mathrm{~m}^{3} \mathrm{ha}^{-1}$.

Therefore, there is an optimal dose, with risks of soil salinization and contamination of ground and surface water when this value is exceeded. In this sense, the amount applied should be monitored, as an excess can also cause negative impacts.

Considering the importance of organic inputs to sustainable agricultural production, this study aimed to evaluate the number of fruits, the fresh mass of fruits, and yield of yellow passion fruit in the first year of cultivation with the application of doses of swine wastewater treated in a biodigester.

\section{MATERIAL AND METHODS}

The experiment was conducted at the Experimental Field of the Federal Institute of Education, Science and Technology of Ceará (IFCE), campus of Crato, CE, Brazil, with approximate geographic coordinates at the central point of the area of $07^{\circ} 12^{\prime} \mathrm{S}$ and $39^{\circ} 27^{\prime} \mathrm{W}$, with an altitude of $660 \mathrm{~m}$ above sea level. The regional climate, according to the Köppen classification, is Aw, corresponding to a humid tropical climate, with a mean annual precipitation of $850 \mathrm{~mm}$, mean 
air temperature of $27{ }^{\circ} \mathrm{C}$, and relative humidity around $75 \%$.

Passion fruit seeds of the yellow variety were used for seedling formation. The seeds were sown in polyethylene bags with dimensions of $0.15 \times$ $0.28 \mathrm{~m}$ filled with quartz sand, hydromorphic soil, and cured bovine manure at a proportion of 2:2:1 $(\mathrm{v} / \mathrm{v})$. Sowing was carried out on September 24, 2016.

The seedlings were transplanted to the field when they reached 0.30 to $0.40 \mathrm{~m}$ in height, on January 3, 2017. The spacing was $5.0 \mathrm{~m}$ between plants and $3.0 \mathrm{~m}$ between rows and three useful plants were evaluated per plot, totaling 60 plants occupying an area of $900.0 \mathrm{~m}^{2}$.

Chemical and physical analyses were performed from the initial collection of soil samples carried out in October 2016 at a depth of $0.00-0.20$ $\mathrm{m}$, according to the methodology suggested by EMBRAPA (2011).

The soil has an acidic reaction, low available phosphorus contents, very low potassium contents, low calcium contents, medium magnesium content, low base and aluminum saturation, medium cation exchange capacity values, and low organic matter contents (SBCS, 2004). Physically, the soil has a loamy sandy texture (Table 1) and is classified as an Argissolo (Ultisol), according to the Brazilian Soil Classification System (EMBRAPA, 2006).

A vertical espalier system, with a wire at 2.0 $\mathrm{m}$ high, was used to train the crop. Wooden posts and stakes were used to construct the espalier system of training. Irrigation was performed based on the potential reference evapotranspiration (ETo), calculated according to the methodology of Hargreaves \& Samani, described by Lima et al. (2016), and using passion fruit crop coefficients $(\mathrm{Kc})$ of $0.65,1.13,1.25$, and 0.82 for the phenological stages formation, flowering, fruiting, and fruit maturation, respectively, found by Medeiros et al. (2009) and Araújo et al. (2006). The irrigation had a daily frequency, totaling an irrigation depth of $943 \mathrm{~mm}$ during the study period (January to November 2017).

A gravity-fed drip irrigation system with a selfcompensating emitter per plant was used to provide a flow rate of $4.0 \mathrm{~L} \mathrm{~h}^{-1}$. The irrigation was carried out to complement the water depth that represented the volume of applied SW doses.

A randomized block design with four replications was used. The treatments consisted of SW doses $\left(\mathrm{D}_{1}=0, \mathrm{D}_{2}=0.50, \mathrm{D}_{3}=1.00, \mathrm{D}_{4}=1.50\right.$, and $\mathrm{D}_{5}=2.00 \mathrm{~L} \mathrm{plant}^{-1}$ ), calculated based on related research (REIS et al., 2018; LIMA et al., 2019; ALVES NETO et al., 2016) from the IFCE swine production unit, campus of Crato, CE, Brazil.

The SW chemical analysis was carried out using the methodology of the Standard Methods for the Examination of Water and Wastewater: Metals by Plasma Emission Spectroscopy (Method 3129), using an inductively coupled plasma optical emission spectrometer, with previous sample digestion, following the guidelines of the Application Book (SK-10 High-Pressure Rotor), with results shown in Table 2.

Table 1. Results of soil chemical and physical analysis in the experimental area

\begin{tabular}{|c|c|c|c|c|c|c|c|c|c|c|}
\hline & \multicolumn{10}{|c|}{ Chemical attributes } \\
\hline \multirow{3}{*}{$\begin{array}{c}\mathrm{pH} \\
\text { water } 1: 2.5 \\
4.9\end{array}$} & $\mathrm{OM}$ & $\mathrm{P}$ & $\mathrm{K}^{+}$ & $\mathrm{Ca}^{2+}$ & $\mathrm{Mg}^{2+}$ & $\mathrm{Na}^{+}$ & $\mathrm{H}^{+}+\mathrm{Al}^{3+}$ & $\mathrm{Al}^{3+}$ & $\mathrm{CEC}$ & $\mathrm{V}$ \\
\hline & $\mathrm{kg} \mathrm{ha}^{-1}$ & $\mathrm{mg} \mathrm{kg}^{-1}$ & \multicolumn{7}{|c|}{$\mathrm{cmol}_{\mathrm{c}} \mathrm{kg}^{-1}$} & $\%$ \\
\hline & 13.34 & 9 & 0.36 & 1.20 & 1.00 & 0.06 & 2.81 & 0.3 & 5.43 & 48.25 \\
\hline \multicolumn{11}{|c|}{ Physical attributes } \\
\hline \multirow[t]{2}{*}{$\mathrm{CS}$} & & FS & $\mathrm{S}$ & $\mathrm{C}$ & $\mathrm{NC}$ & \multirow{2}{*}{ 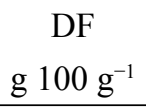 } & Ds & $\mathrm{Dp}$ & \multicolumn{2}{|c|}{$\mathrm{TC}$} \\
\hline & \multicolumn{5}{|c|}{$\mathrm{g} \mathrm{kg}^{-1}$} & & \multicolumn{2}{|c|}{$\mathrm{g} \mathrm{cm}^{-3}$} & & \\
\hline 580 & & 234 & 65 & 112 & 40 & 64 & 1.5 & 2.7 & \multicolumn{2}{|c|}{ Loamy sandy } \\
\hline
\end{tabular}


VÁSQUEZ, M A. N. et al.

Table 2. Chemical characterization of swine wastewater treated in a biodigester and applied to the treatments

\begin{tabular}{cccc}
\hline Macronutrient contents $\left(\mathrm{mg} \mathrm{L}^{-1}\right)$ & \multicolumn{2}{c}{ Micronutrient contents $\left(\mathrm{mg} \mathrm{L}^{-1}\right)$} \\
\hline $\mathrm{N}$ & 377.5 & $\mathrm{Cu}$ & 1.9 \\
$\mathrm{P}$ & 47.8 & $\mathrm{Mn}$ & 4.0 \\
$\mathrm{~K}$ & 188.1 & $\mathrm{~B}$ & 5.67 \\
$\mathrm{Ca}$ & 85.0 & $\mathrm{Fe}$ & 2.55 \\
$\mathrm{Mg}$ & 74.6 & $\mathrm{Mo}$ & 0.03 \\
& & $\mathrm{Zn}$ & 31.11 \\
\hline $\mathrm{pH}$ & 6.5 & $\mathrm{EC}$ & $1.45 \mathrm{dS} \mathrm{m}^{-1}$ \\
\hline
\end{tabular}

$\mathrm{N}$ - nitrogen; $\mathrm{P}$ - phosphorus; $\mathrm{K}$ - potassium; $\mathrm{Ca}$ - calcium; $\mathrm{Mg}$ - magnesium; $\mathrm{Cu}$ - copper; $\mathrm{Zn}$ - zinc; $\mathrm{Mn}$ - manganese; $\mathrm{B}$ - boron; Fe - iron; Mo - Molybdenum; EC - electrical conductivity

The values were lower than those applied by $\mathrm{Da}$ Cruz et al. (2008) on yellow passion fruit seedlings and higher than those applied by Junior et al. (2009) on the growth and production of yellow passion fruit, except for $\mathrm{K}$ and $\mathrm{Zn}$.

After transplanting, plants at the initial vegetative growth stage were tied and had their lateral shoots pruned, in a single stalk. Leaf sprayings and chemical fertilizers were not applied during the plant formation period.

The first SW application was carried out at the vegetative period, two months after transplanting, with the second application conducted at the beginning of flowering, with half of the SW dose at each stage, according to the treatment.

The first and last planting row and first and last plant of each row were used as borders. Harvesting started in the eighth month after transplanting, during the first week of August 2017. Fruits with more than $30 \%$ yellow, as well as those that fell, were harvested once or twice a week, with monthly sums for statistical analysis.

The number of commercial fruits (60 to 110 $\mathrm{mm}$ in transversal diameter) was evaluated by counting all the fruits harvested from the useful area of each plot. The fruit mass $(\mathrm{g})$ and the mean production per plant $(\mathrm{g})$ were also determined. The yield estimate was obtained by multiplying the mean production per plant by the number of plants per hectare (666.7 plants ha $\left.{ }^{-1}\right)$.

The data were subjected to analysis of variance using the F-test at a 5\% probability to verify significance. The evaluation of SW doses applied to the passion fruit plants was carried out by regression analysis, using the statistical program SISVAR v. 5.3 (FERREIRA, 2011).

\section{RESULTS AND DISCUSSION}

The weather variables related to precipitation $(\mathrm{mm})$, relative air humidity (\%), maximum, minimum, and mean temperatures $\left({ }^{\circ} \mathrm{C}\right)$, and wind speed $\left(\mathrm{m} \mathrm{s}^{-1}\right)$ that occurred during the passion fruit development and production (January to November 2017) are shown in Figures 1 and 2.

The highest precipitations occurred during the first four months $(199,222,166$, and $100 \mathrm{~mm})$, but the period from May to October 2017 showed practically no precipitation, with accumulated values reaching $832 \mathrm{~mm}$. The relative air humidity ranged from 63 to $87 \%$, with the lowest values recorded in the hottest months. The maximum, minimum, and mean temperature values indicated little variation during the year, with values of 33 , 21 , and $26^{\circ} \mathrm{C}$, respectively.

The maximum wind speed values did not exceed $5 \mathrm{~m} \mathrm{~s}^{-1}$, not causing damages to flowering and fruiting.

Table 3 shows the mean number of commercial fruits (NCF) as a function of the months of production for different $\mathrm{SW}$ doses. The regression analysis presented a significant effect for NCF in all months, with a high coefficient of determination $\left(\mathrm{R}^{2}\right)(89.85$ to $99.06 \%)$. The linear regression model was the best fit $(\mathrm{p}<0.05)$ for August and September and also for the means, that is, NCF increased as SW doses increased. On the contrary, the quadratic regression model was the best fit $(\mathrm{p}<$ 


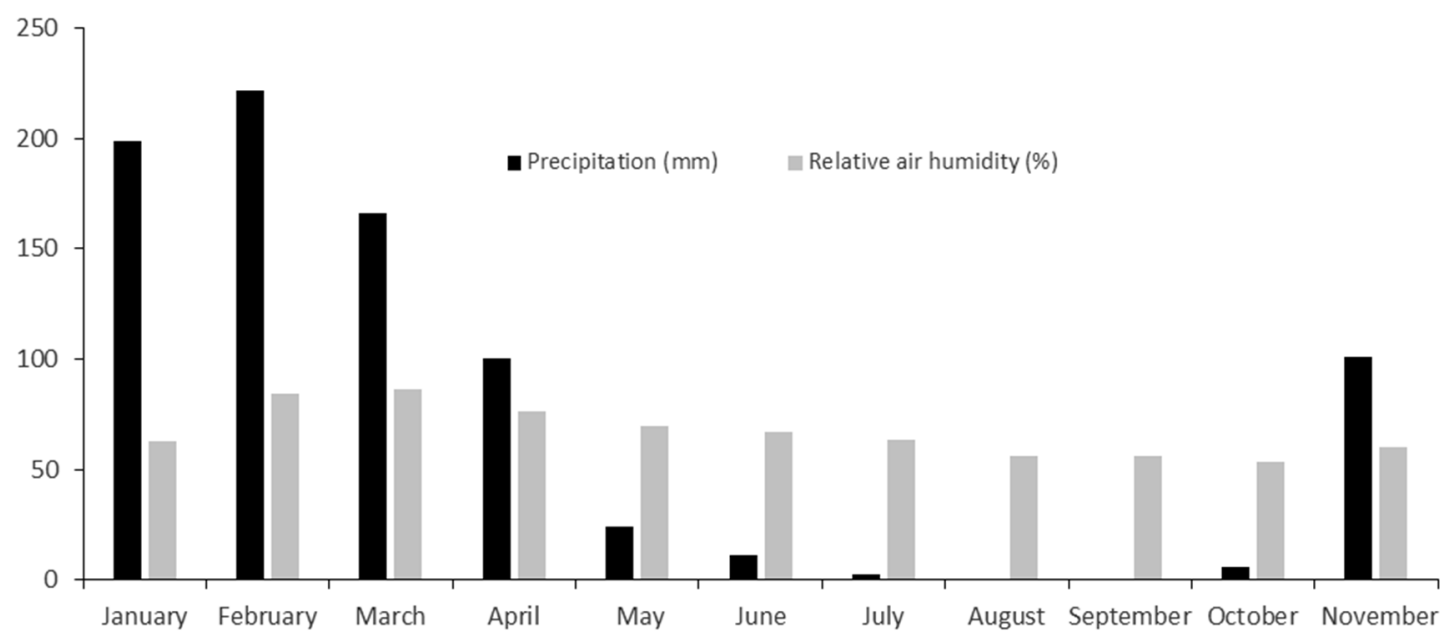

Figure 1. Precipitation (mm) and relative air humidity (\%) observed from January to November 2017. Weather Station of Barbalha, CE, Brazil, 2020, $20 \mathrm{~km}$ away from the experimental site. Source: BDMEP-INMET Network

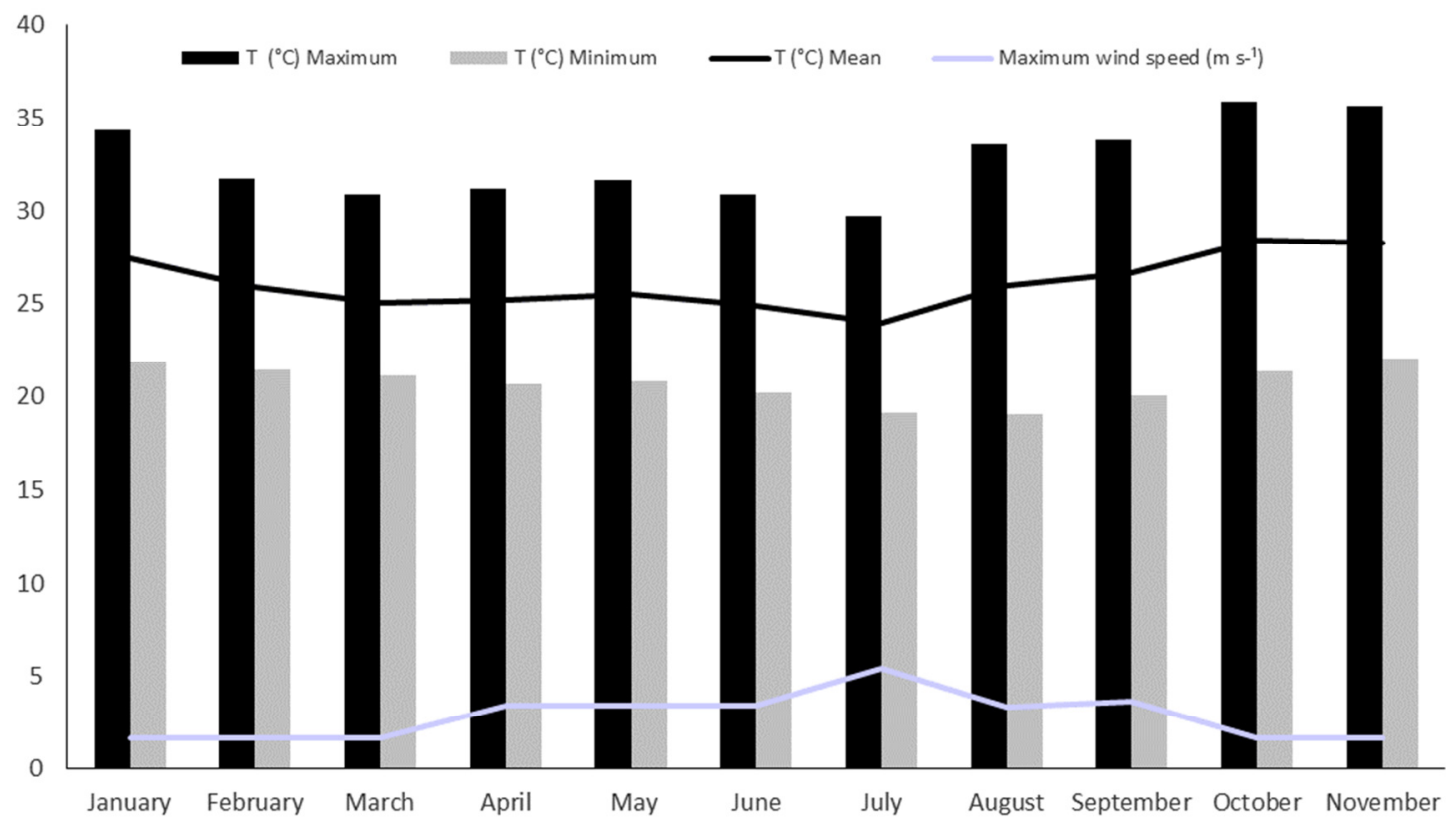

Figure 2. Maximum, minimum, and mean temperatures $\left({ }^{\circ} \mathrm{C}\right)$ observed from January to November 2017. Weather Station of Barbalha, CE, Brazil, 2020, $20 \mathrm{~km}$ away from the experimental site. Source: BDMEP-INMET Network

0.05) for October, that is, NCF increased up to the $\mathrm{SW}$ dose of $1 \mathrm{~L}_{\text {plant }}{ }^{-1}$, with a slight decrease under higher doses.

Similarly, the quadratic model was the best fit for November, with effects of increased NCF only for the highest SW doses (1.5 and 2.0 L plant $\left.{ }^{-1}\right)$ and a slight decrease in NCF probably due to the end of the production cycle, with reduced flowering and fruiting at this period.

The comparison of the same SW dose applied between the production months also presented the same trend, with October showing the highest variation probably due to higher temperatures and relative air humidity, which provided better plant performance in a less favorable for pest and disease proliferation. 
VÁSQUEZ, M A. N. et al.

Table 3. Mean number of commercial fruits (NCF) for the production months as a function of the application of different doses of swine wastewater treated in a biodigester

\begin{tabular}{|c|c|c|c|c|c|}
\hline \multirow{2}{*}{ Treat. } & \multicolumn{4}{|c|}{ Production period } & \multirow{2}{*}{ Mean } \\
\hline & August & September & October & November & \\
\hline $\mathrm{D}_{1}$ & $1.25 \mathrm{Bb}$ & $2.63 \mathrm{BAb}$ & $11.13 \mathrm{Cb}$ & $6.42 \mathrm{Ab}$ & $5.36 \mathrm{Bb}$ \\
\hline $\mathrm{D}_{2}$ & $1.58 \mathrm{Bba}$ & $5.00 \mathrm{Bba}$ & $23.57 \mathrm{Ab}$ & $5.17 \mathrm{Bb}$ & $8.84 \mathrm{Bba}$ \\
\hline $\mathrm{D}_{3}$ & 2.08 Bba & $5.79 \mathrm{Ba}$ & $26.75 \mathrm{Ab}$ & $4.75 \mathrm{Bb}$ & $9.85 \mathrm{Ba}$ \\
\hline $\mathrm{D}_{4}$ & $3.50 \mathrm{Bba}$ & $7.50 \mathrm{Ba}$ & $26.33 \mathrm{Ab}$ & 12.88 BAba & $12.55 \mathrm{BAa}$ \\
\hline $\mathrm{D}_{5}$ & $4.50 \mathrm{Ba}$ & $8.00 \mathrm{Ba}$ & $18.46 \mathrm{Ab}$ & $18.25 \mathrm{Aa}$ & $12.30 \mathrm{Ba}$ \\
\hline Mean & 2.58 & 5.78 & 21.25 & 9.49 & 9.78 \\
\hline CV $(\%)$ & 54.26 & 23.38 & 35.94 & 50.71 & 20.04 \\
\hline $\mathrm{R}^{2}(\%)$ & $93.92 *$ & $95.16^{*}$ & $99.06^{*}$ & $95.36^{*}$ & $89.85 *$ \\
\hline Model & Linear & Linear & Quadratic & Quadratic & Linear \\
\hline
\end{tabular}

Regression equations - August: $\mathrm{y}=0.842 \mathrm{x}+0.058$; September: $\mathrm{y}=1.325 \mathrm{x}+1.809$; October: $\mathrm{y}=-3.159 \mathrm{x}^{2}+20.702 \mathrm{x}-6.1 ;$ November: $\mathrm{y}=1.557 \mathrm{x}^{2}$ $-6.202 x+10.977$; Mean: $y=1.761 x+4.496$. Means followed by the same uppercase letter (month comparison) and the same lowercase letter (different doses) do not differ from each other by the F-test at the $5 \%$ significance level

The variation in NCF during the harvest months may have occurred due to climate variations at the plant vegetative development stages, variations in the number of flowers per plant to be pollinated, the formation pruning management, and nutrient availability, such as $\mathrm{N}, \mathrm{P}$, and $\mathrm{K}$ in the soil from SW, as indicated by Gomes Filho et al. (2001). The values are lower than those found by Menezes et al. (2017) in the "Guinezinho" and "Gigante Amarelo" genotypes, which reached means of 35.15 and 34.15 fruits plant $^{-1}$, respectively, using the maximum fertilizer dose (40\%) and responding linearly to the biofertilizer doses.

The values were also lower than those found by Rodrigues et al. (2009) with supermagro biofertilizer and potassium $(1.43,0.26,1.01,0.49$, and $0.26 \mathrm{~g} \mathrm{~kg}^{-1}$ of $\mathrm{N}, \mathrm{P}, \mathrm{K}, \mathrm{Ca}$, and $\mathrm{Mg}$, respectively, and $439,332,155,961$, and $1699 \mathrm{mg} \mathrm{kg}^{-1}$ of $\mathrm{B}$, $\mathrm{Cu}, \mathrm{Fe}, \mathrm{Mn}$, and $\mathrm{Zn}$, respectively, with $\mathrm{pH} 4.6$ and electrical conductivity of $13.18 \mathrm{dS} \mathrm{m}^{-1}$ ) compared to the highest applied SW dose $(0.76,0.09,0.38$, 0.17 , and $0.15 \mathrm{~g} \mathrm{~L}^{-1}$ of $\mathrm{N}, \mathrm{P}, \mathrm{K}, \mathrm{Ca}$, and $\mathrm{Mg}$, respectively, and $11.34,3.8,5.1,0.1$, and 62.22 $\mathrm{mg} \mathrm{L}^{-1}$ of $\mathrm{B}, \mathrm{Cu}, \mathrm{Fe}, \mathrm{Mn}$, and $\mathrm{Zn}$, respectively, with $\mathrm{pH} 6.5$ and electrical conductivity of $1.45 \mathrm{dS}$ $\mathrm{m}^{-1}$ ), which ranged from 80 to 96 fruits plant ${ }^{-1}$ and presented an overall mean of 86.6 fruits plant $^{-1}$. Moreover, Collard et al. (2001) found 139 fruits plant $^{-1}$ in a field sprayed monthly with agrobio $\left(0.63,0.17,1.2,1.59\right.$, and $0.48 \mathrm{~g} \mathrm{~L}^{-1}$ of $\mathrm{N}, \mathrm{P}, \mathrm{K}$, $\mathrm{Ca}$, and $\mathrm{Mg}$, respectively, with $\mathrm{pH}$ ranging from 5 to 6). Similarly, Cavalcante et al. (2007) recorded between 52 to 65 fruits plant ${ }^{-1}$ in soil treated with supermagro (13.1 and 8.5, 2.9 and 8.5, 6.7 and 8.2, 4.3 and 19.2 , and 0.8 and $1.9 \mathrm{~g} \mathrm{~kg}^{-1}$ of N, P, K, Ca, and $\mathrm{Mg}$ in mixtures with water, with an electrical conductivity of 2.8 and $4.6 \mathrm{dS} \mathrm{m}^{-1}$, respectively).

The highest fruit production reported by the authors compared to the data from the present study shows higher efficiency of the input, its chemical complexity, which increases the availability of some nutrients, the higher concentration, and more frequent application.

Dias et al. (2017) evaluated passion fruit production and quality after fertilization with nitrogen and potassium $(0-0,50-125,100-250$, $150-375,200-500$, and $250-625 \mathrm{~kg} \mathrm{ha}^{-1}$ year $^{-1}$ of $\mathrm{N}$ and $\mathrm{K}_{2} \mathrm{O}$ ) and found that the number of fruits per plant ranged from 192 to 298, which are higher than the values found in the present study when comparing the nitrogen and potassium contents found in the applied SW doses (126-75, 253-150, $378-226$, and $503-301 \mathrm{~kg} \mathrm{ha}^{-1}$ year $^{-1}$ of $\mathrm{N}$ and $\mathrm{K}_{2} \mathrm{O}$ ), even with higher $\mathrm{N}$ amounts. Furthermore, the number of fruits per plant results found in the present study were lower than those observed by Oliveira (2017), who verified that an increase in nitrogen up to the dose of $203 \mathrm{~kg} \mathrm{ha}^{-1}$ provided the highest number of fruits (165) per plant.

The obtained coefficients of variation ranged from 20.04 to $54.26 \%$, not showing a good precision of the assays. This oscillation may be 
due to the high precipitations at the time of the first application of the doses, the vegetative state, the management and plant training conditions, with variations in the number of productive branches per plant, the non-use of artificial pollination method, and the natural soil fertility.

The mean fresh fruit mass (FFM) (Table 4) as a function of production months for the different SW doses showed a significant difference for August, when only $\mathrm{D}_{1}$ provided a difference from the other doses, with values ranging from 132.59 to $229.39 \mathrm{~g}$.

The regression analysis of the mean fresh fruit mass (FFM) for the different SW doses in the different harvest months (Table 4) did not fit the linear or quadratic regression models, with significance found only for the cubic model for August, with higher FFM for the treatment that did not receive the SW dose probably due to the lower number of fruits that had the highest initial development with the natural soil fertility and, consequently, higher mass, with also an oscillation of FFM for the other doses.

The comparison of the applied SW doses between production months showed that August and October had higher FFM variation, especially for the $\mathrm{D}_{1}$ and $\mathrm{D}_{5}$ doses, probably due to the natural soil fertility and the initial contributions of the nutrients supplied by SW.

The results found in this study for August are very close to the values reported by Reis et al. (2018) for monthly applications using swine wastewater at a dose of $2 \mathrm{~L}_{\text {plant }}{ }^{-1}$ throughout the cycle of different passion fruit varieties, being significant for March, with a mean mass ranging from 171 to $238 \mathrm{~g}_{\text {fruit }}{ }^{-1}$.

Similarly, Andrade et al. (2017) found a fresh mass of yellow passion fruit cv. Redondo Amarelo weighing $201.8 \mathrm{~g}$, in plants formed with 25-day seedlings with organic and mineral fertilization. This value is also higher than those found by Nascimento et al. (2003), Hafle et al. (2009), and Cunha (2013), who obtained mean fruit masses of 193, 161.6, and $123.8 \mathrm{~g}$ for the cultivar Redondo Amarelo, respectively.

The value was also lower than that found by Rodolfo Junior et al. (2008) for the first production season (November/2005 to February/2006), with a value of $181.4 \mathrm{~g}$ corresponding to plots treated with common and supermagro biofertilizers in the absence of the NPK mineral fertilizer, and even lower than the results found by Santos (2004), who obtained values of 176 and $180 \mathrm{~g}$ per fruit with the use of common and supermagro biofertilizer.

However, the FFM values obtained in this study were higher than those found by Abreu et al. (2009) under a conventional system, with $129.4 \mathrm{~g}$ for the cultivar Gigante Amarelo and $127.8 \mathrm{~g}$ for the cultivar Rubi do Cerrado.

The linear regression model best fit $(p<0.05)$ the monthly yield (MY) of passion fruits in tons per hectare as a function of the applied SW doses (Table 5) for August, September, and November, with production increments with an increase in

Table 4. Mean fresh fruit mass (FFM) (g) for production months as a function of the application of different doses of swine wastewater from treated in a biodigester

\begin{tabular}{|c|c|c|c|c|c|}
\hline \multirow{2}{*}{ Treat. } & \multicolumn{4}{|c|}{ Production period } & \multirow{2}{*}{ Mean } \\
\hline & August & September & October & November & \\
\hline $\mathrm{D}_{1}$ & $229.39 \mathrm{Aa}$ & $139.56 \mathrm{Bb}$ & 157.62 BAb & $92.50 \mathrm{Bb}$ & $140.95 \mathrm{Bb}$ \\
\hline $\mathrm{D}_{2}$ & $132.59 \mathrm{Bb}$ & $102.71 \mathrm{Bb}$ & $140.37 \mathrm{Bb}$ & $96.95 \mathrm{Bb}$ & $130.11 \mathrm{Bb}$ \\
\hline $\mathrm{D}_{3}$ & $202.99 \mathrm{Bba}$ & $148.63 \mathrm{Bb}$ & $155.84 \mathrm{Bb}$ & $113.85 \mathrm{Bb}$ & $146.43 \mathrm{Bb}$ \\
\hline $\mathrm{D}_{4}$ & 194.39 Bba & $122.32 \mathrm{Bb}$ & $132.99 \mathrm{Bb}$ & $120.37 \mathrm{Bb}$ & $130.61 \mathrm{Bb}$ \\
\hline $\mathrm{D}_{5}$ & $212.28 \mathrm{Aba}$ & $142.79 \mathrm{BAb}$ & 151.88 BAb & $100.65 \mathrm{Bb}$ & $136.69 \mathrm{Bb}$ \\
\hline Mean & 194.33 & 131.20 & 147.74 & 104.86 & 136.96 \\
\hline CV (\%) & 20.87 & 37.66 & 22.94 & 25.85 & 19.11 \\
\hline $\mathrm{R}^{2}(\%)$ & $67.50 *$ & & & & \\
\hline Model & Cubic & & & & \\
\hline
\end{tabular}

Regression equation - August: $\mathrm{y}=-11.726 \mathrm{x}^{3}+116.271 \mathrm{x}^{2}-338.411 \mathrm{x}+458.228$. Means followed by the same uppercase letter (month comparison) and the same lowercase letter (different doses) do not differ from each other by the F-test at the $5 \%$ significance level 
SW doses and a high coefficient of determination $\left(\mathrm{R}^{2}\right)$, with values ranging from 72.96 to $96.81 \%$. On the contrary, the quadratic regression model was the best fit $(p<0.05)$ for MY in October, with increments in NCF up to the SW dose of $1.5 \mathrm{~L}$ plant $^{-1}$ and a slight decrease under higher doses.

The comparison of the applied SW doses between production months shows that October had a higher MY variation, probably due to the peak of flowering, pollination, and fruiting in August and September, with favorable environmental conditions and the presence of natural pollinators.

The peak of yield was reached in October, that is, ten months after planting. Low yields were observed per month compared to other studies, such as Reis et al. (2018), who studied the same crop at spacings of $5 \mathrm{~m}$ between plants and $2.5 \mathrm{~m}$ between rows and found a mean monthly yield from 0.69 to $5.53 \mathrm{t} \mathrm{ha}^{-1}$ for different cultivars, as the swine wastewater doses were associated with topdressing organic fertilization and NPK applications at production period. However, no significant differences were observed between cultivars in some production months.

The total mean yield (TY) of passion fruit $(t$ $\mathrm{ha}^{-1}$ ) as a function of the applied SW doses is shown in Figure 3. The linear regression model was the best fit $(\mathrm{p}<0.05)$ for TY, with a high coefficient of determination $\left(\mathrm{R}^{2}\right)$ of $94.08 \%$. TY ranged from 2.03 and $4.43 \mathrm{t} \mathrm{ha}^{-1}$, with no differences between treatments that received $\mathrm{SW}$ doses but differing from the control treatment. An increase in yield from $0.98 \mathrm{t} \mathrm{ha}^{-1}$ for the lowest dose $\left(\mathrm{D}_{2}\right)$ to $2.4 \mathrm{t}$ $\mathrm{ha}^{-1}$ for the highest dose $\left(\mathrm{D}_{5}\right)$ was also observed.

Silva et al. (2015) evaluated the effect of humic substances and nitrogen fertilization (180, $200,260,330$, and $350 \mathrm{~kg} \mathrm{ha}^{-1}$ of N) on passion fruit cultivation in the semiarid region of Brazil (Juazeiro, Bahia) and verified a production value of $17.5 \mathrm{tha}^{-1}$ at the dose of $350 \mathrm{~kg} \mathrm{ha}^{-1}$ of $\mathrm{N}$, which is higher than the production found in the present study for the applied SW doses $(126,253,378$, and $503 \mathrm{~kg} \mathrm{ha}^{-1}$ of $\mathrm{N}$ ), possibly because nitrogen provides higher vegetative development at the expense of flower and fruit production.

Moreover, Diniz et al. (2020) observed that a balanced NPK fertilization favors mineral nutrition of passion fruit plants, with a mean yield around 22.1 tha $^{-1}$ when $244 \mathrm{~kg} \mathrm{ha}^{-1}$ of $\mathrm{N}, 72 \mathrm{kgha}^{-1}$ of $\mathrm{P}_{2} \mathrm{O}_{5}$, and $285 \mathrm{~kg} \mathrm{ha}^{-1}$ of $\mathrm{K}_{2} \mathrm{O}$ are supplied. However, a lower production is observed even considering the highest SW dose used in the present study $(503.33$ $\mathrm{kg} \mathrm{ha}^{-1}$ of $\mathrm{N}, 145.96 \mathrm{~kg} \mathrm{ha}^{-1}$ of $\mathrm{P}_{2} \mathrm{O}_{5}$, and $300.96 \mathrm{~kg}$ $\mathrm{ha}^{-1}$ of $\mathrm{K}_{2} \mathrm{O}$ ), which is mainly due to the nutritional imbalance.

The TY values were lower than those found by Menezes et al. (2017) for the genotypes Guinezinho and Gigante Amarelo, with yields of 14.97 and $12.54 \mathrm{tha}^{-1}$, respectively, with the application of $40 \%$ of biofertilizer. Similarly, Rodolfo Júnior et al. (2009) obtained a yellow passion fruit yield of $25.95 \mathrm{tha}^{-1}$ in the first year of cultivation for soil

Table 5. Mean yield (PM) of passion fruit $\left(\mathrm{t} \mathrm{ha}^{-1}\right)$ for production months as a function of the application of different doses of swine wastewater treated in a biodigester

\begin{tabular}{ccccc}
\hline \multirow{2}{*}{ Treat. } & \multicolumn{4}{c}{ Production period $\left(\mathrm{t} \mathrm{ha}^{-1}\right)$} \\
\cline { 2 - 4 } & August & September & October & November \\
\hline $\mathrm{D}_{1}$ & $0.19 \mathrm{Bba}$ & $0.25 \mathrm{Bb}$ & $1.19 \mathrm{Ab}$ & $0.41 \mathrm{Bb}$ \\
$\mathrm{D}_{2}$ & $0.13 \mathrm{Bb}$ & $0.39 \mathrm{Bba}$ & $2.15 \mathrm{Ab}$ & $0.33 \mathrm{Bb}$ \\
$\mathrm{D}_{3}$ & $0.28 \mathrm{Bba}$ & $0.59 \mathrm{Bba}$ & $2.46 \mathrm{Ab}$ & $0.34 \mathrm{Bb}$ \\
$\mathrm{D}_{4}$ & $0.49 \mathrm{Bba}$ & $0.61 \mathrm{Bba}$ & $2.09 \mathrm{Ab}$ & $1.13 \mathrm{BAb}$ \\
$\mathrm{D}_{5}$ & $0.64 \mathrm{Ba}$ & $0.76 \mathrm{Ba}$ & $1.81 \mathrm{Ab}$ & $1.23 \mathrm{BAb}$ \\
\hline Mean & 0.35 & 0.52 & 1.94 & 0.69 \\
\hline $\mathrm{CV}(\%)$ & 64.06 & 40.33 & 30.45 & 85.05 \\
\hline $\mathrm{R}^{2}(\%)$ & $87.15^{*}$ & $96.81^{*}$ & $93.33^{*}$ & $72.96^{*}$ \\
\hline Model & Linear & Linear & Quadratic & Linear
\end{tabular}

Regression equations - August: $y=0.125 x-0.030$; September: $y=0.125 x+0.147$; October: $y=-0.227 x^{2}+1.477 x-0.001 ;$ November: $y=0.245 x$ - 0.048. Means followed by the same uppercase letter (month comparison) and the same lowercase letter (different doses) do not differ from each other by the F-test at the $5 \%$ significance level 


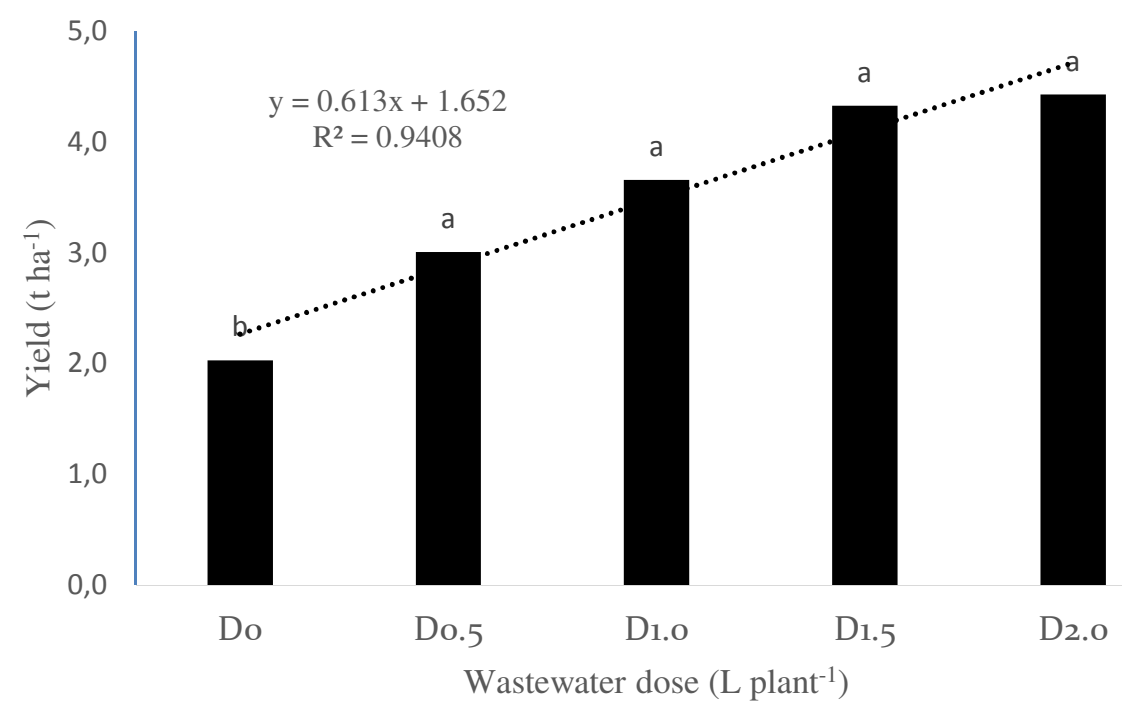

Figure 3. Total yield of passion fruit $\left(\mathrm{t} \mathrm{ha}^{-1}\right)$ as a function of doses of swine wastewater treated in a biodigester. Means followed by the same letter do not differ from each other by the F-test at the $5 \%$ significance level

treated with a common biofertilizer.

Moreover, Neto et al. (2009) evaluated the yield and vigor of yellow passion fruit planted in different pit sizes and no-till under organic management and found a mean yield of $10.2 \mathrm{t} \mathrm{ha}^{-1}$. These results were also higher than those found by Reis et al. (2018), with values ranging from 16 and $19 \mathrm{tha}^{-1}$.

As observed by Krause et al. (2012), a factor that may have influenced yield, in addition to the low nutrient supply to the soil by the wastewater, was the lack of manual pollination, which. The manual pollination provided yields of up to 16.46 $\mathrm{t} \mathrm{ha}^{-1}$, while the natural pollination provided yields of only $5.92 \mathrm{t} \mathrm{ha}^{-1}$, considering the same cultivars.

A favorable response was observed to the analyzed variables with an increase in SW doses. Gomes Filho et al. (2001) observed that wastewater may present nutrients in sufficient quantities for crops after passing through the biodigester, leading to increased production and yield, with two-thirds of nitrogen, one-third of phosphorus, and almost $100 \%$ of potassium being found in the mineral form, that is, readily available for crops.

\section{CONCLUSIONS}

- The number of fruits of passion fruit increased with the doses of swine wastewater from a biodigester under the studied conditions. The pattern of increments in the number of fruits was similar in November despite the numerical differences.

- No difference was observed between harvest periods for the fresh fruit mass. However, a difference was observed in the final mean yield between the analyzed doses, considering the four production months.

- The mean yields achieved with the passion fruit cultivation under the highest dose of swine wastewater from a biodigester were considered satisfactory.

\section{AUTHORSHIP CONTRIBUTION STATEMENT}

VÁSQUEZ, M.A.N.: Conceptualization, Methodology, Validation, Writing - original draft, Writing - review \& editing; SANTOS, A.M.S.: Data curation, Formal Analysis, Investigation, Project administration, Supervision; OLIVEIRA, D.F.: Data curation, Methodology, Supervision, Validation, Visualization; VÁSQUEZ, E.M.F.: Investigation, Methodology, Validation, Visualization, Writing - review \& editing; SANTOS, F.G.B.: Investigation, Methodology, Supervision, Visualization, Writing - review \& editing; SOUSA, F.R.R.: Investigation, 
Methodology, Validation, Visualization, Writing review \& editing.

\section{DECLARATION OF INTERESTS}

The authors declare that they have no known competing financial interests or personal relationships that could have appeared to influence the work reported in this paper.

\section{ACKNOWLEDGMENTS}

To the Federal Institute of Education, Science, and Technology of Ceará, campus of Crato, CE, Brazil, for granting scholarships to the students, materials, and facilities.

\section{REFERENCES}

ABREU, S. DE P. M.; PEIXOTO, J. R.; VILELA JUNQUEIRA, N. T.; DE FIGUEIREDO, S. M. A. Características físico-químicas de cinco genótipos de maracujazeiro azedo cultivados no distrito federal. Revista Brasileira de Fruticultura, v. 31, n. 2, p. 487-491, 2009.

ALVES NETO, A. J.; LANA, M. C.; RAMPIM, L.; MENDONÇA COSTA, L. A.; COPPO, J, C.; ALVES, A. G. Água residuária de suinocultura sobre a produtividade de soja e milho segunda safra: uso e viabilidade econômica. Revista Scientia Agraria Paranaensis, v. 15, n. 3, p. 350357, 2016.

ANDRADE dos S. V.; RAMOS, J. D.; REIS, R. L.; SILVA; F, O.; CHAGAS, E. A.; PASQUAL, M. Produção e qualidade de frutos de maracujazeiroamarelo provenientes do cultivo com mudas em diferentes idades. Revista de Ciências Agroveterinárias, v.16, n.1, p.33-40, 2017.

ARAÚJO, J. F.; SANTANA, M. D. B.; NETO, J. P.; SILVA, F. M. D.; SILVA, N. M. C. Crescimento de mudas de maracujá amarelo com biofertilizante líquido. In: VII CONNEPI-Congresso Norte Nordeste de Pesquisa e Inovação, 2012.

ARAÚJO S., T. J.; FOLEGATTI, M. V.; SILVA, C. R.; ALVES J., J.; MATOS P., R. C. Evapotranspiração e coeficientes de cultura do maracujazeiro amarelo conduzido sob duas orientações de plantio. Irriga, v.11, n.1, p. 90-106, 2006.
BERNACCI, L. C.; SOARES-SCOTT, M. D.; VILELA JUNQUEIRA, N. T.; DA SILVA, P. I. R.; MOLINA MELETTI, L. M. Passiflora edulis Sims: the correct taxonomic way to cite the yellow passion fruit (and of others colors). Revista Brasileira de Fruticultura, 30: 566-576, 2008.

CAVALCANTE, L. F.; DOS SANTOS, G. D.; DE OLIVEIR, F. A.; CAVALCANTE. I. H. L.; GONDIM, S. C.; CAVALCANTE, M. Z. B. Crescimento e produção do maracujazeiroamarelo em solo de baixa fertilidade tratado com biofertilizantes líquidos. Revista Brasileira de Ciências Agrárias, v.2, n.1, p.15-19, 2007.

COLLARD, F. H.; ALMEIDA, A.; COSTA, M. D. R.; ROCHA, M. C. Efeito do uso do biofertilizante Agrobio na cultura do maracujazeiro amarelo (Passiflora edulis f. flavicarpa Deg). Revista Biociências, v.7, n.1, p.15-21, 2001.

CUNHA, M. Produtividade e características de frutos de pomares de maracujá implantados com sementes originais e reaproveitadas do híbrido BRS Gigante Amarelo. 46 f. Dissertação (Mestrado em Agronomia: Área de Concentração em Produção Sustentável) - Universidade de Brasília, Brasília, 2013.

DA CRUZ, M. do C. M; RAMOS, J.D.; DE OLIVEIRA, D. L.; MARQUES, V. B.; HAFLE, O. M. Utilização de água residuária de suinocultura na produção de mudas de maracujazeiro-azedo cv redondo amarelo. Revista Brasileira de Fruticultura, v. 30, n. 4, p. 1107-1112, 2008.

DA ROS, C. O.; RODRIGUES DA S., V.; SILVESTRIN, T. B.; FERREIRA DA S., R.; PESSOTTO, P. P. Disponibilidade de nutrientes e acidez do solo após aplicações sucessivas de água residuária de suinocultura. Revista Brasileira de Tecnologia Agropecuária, v. 1, n. 1, p. 35-4, 2017.

DIAS, D. G.; PEGORARO, R. F.; MAIA, V. M.; MEDEIROS, A. C. Production and postharvest quality of irrigated passion fruit after N-K fertilization. Revista Brasileira de Fruticultura, v.39, n.3, p.1- 12, 2017. 
DINIZ, A. A.; CAVALCANTE, L. F.; SOUTO, A. G. L.; CARDOSO, E. A.; SOUTO, P. C.; MENDOÇA, R. M. N.; DIAS, N. S. Leaf composition and productivity of yellow passion fruit (Passiflora edulis Sims.) Access "Guinezinho" in soil with bovine biofertilizer and nitrogen. Australian Jounal of Crop Science, v.12, n.1, p.133-139, 2020.

EMBRAPA - Empresa Brasileira de Pesquisa Agropecuária. Centro Nacional de Pesquisa de Solos. Manual de métodos de análise de solo. 2 ed. revisada, Rio de Janeiro: CNPS, 2011.

EMBRAPA - Empresa Brasileira de Pesquisa Agropecuária. Centro Nacional de Pesquisa de Solos. Sistema Brasileiro de Classificação de Solos. 2 ed. Rio de Janeiro, RJ. 2006.

FERREIRA, D. F. SISVAR: Sistema de análise de variância para dados balanceados, versão 5.3. Lavras: DEX/UFLA, 2011.

GOMES FILHO, R. R.; MATOS, A. T.; SILVA, D. D.; MARTINEZ, H. E. P. Remoção de carga orgânica e produtividade da aveia forrageira em cultivo hidropônico com águas residuárias da suinocultura. Revista Brasileira de Engenharia Agrí́cola e Ambiental, v.5, n.1, p.131-134, 2001.

HAFLE, O. M.; RAMOS, J. D.; DE OLIVEIRAL. L. C.; FERREIRA, E. A.; MELO, P. C. Produtividade e qualidade de frutos do maracujazeiro-amarelo submetido à poda de ramos produtivos. Revista Brasileira de Fruticultura, v. 31, p. 763-770. 2009.

JUNIOR, F. R.; CAVALCANTE, L. F.; BURITI, E. DE S. Crescimento e produção do maracujazeiroamarelo em solo com biofertilizantes e adubação mineral com NPK. Caatinga, v.22, n.2, p.149-160, 2009.

KRAUSE, W.; NEVES, L. G.; VIANA, A. P.; ARAÚJO C. A. T. \& FALEIRO, F. G. Produtividade e qualidade de frutos de cultivares de maracujazeiro-amarelo com ou sem polinização artificial. Pesquisa agropecuária brasileira, 47(12):1737-1742, 2012.
LIMA, C. J. G. S.; DA SILVA, P. L.; DA SILVA, T. O.; PINTO, S. N.; RODRIGUES, A. C.; PINHEIRO, L. A. Soil changes and yield of maize fertilized with swine wastewater. Revista Caatinga, v. 32, n. 1, p. 167 - 178, 2019.

LIMA, J. J.; DUARTE, A. F. D.; BRANCO, O. J.; LIMA, N. F. A.; GOMES, M. K. Parametrização da equação de Hargreaves e Samani para estimativada evapotranspiração de referência no Estado do Ceará, Brasil. Revista Ciência Agronômica, v. 47, n. 3, p. 447-454, 2016.

MARROCOS, S. T.P.; NOVO, J. J.; GRANGEIRO, L. C.; AMBROSIO, M. M. Q.; CUNHA, A. P. A. Composição química e microbiológica de biofertilizantes em diferentes tempos de decomposição. Revista Caatinga, v. 25, n. 4, p. 34-43, 2012.

MEDEIROS, S. M. S.; LIMA, B. F. M.; ARAÚJO, T. V.; TEÓFILO, E. M.; LUCENA, C. I. H. Evapotranspiração do maracujá nas condições do Vale do Curu. Caatinga, v.22, n.2, p.11-16, 2009.

MELETTI, L. M. M. Avanços na cultura do maracujá no Brasil. Revista Brasileira de Fruticultura, v. 33, p. 83-91, 2011

MELLEK, J. E.; DIECKOW, J.; SILVA, V. L.; FAVARETTO, N.; PAULETTI, V.; VEZZANI, F. M.; SOUZA, J. L. M. Dairy liquid manure and notillage: Physical and hydraulic carbon properties and stocks in a Cambisol of Southern Brazil. Soil \& Tillage Research, v. 110, p. 69-76, 2010.

MENEZES, A. V.; CAVALCANTE, L. F.; SILVA, R. M.; GUEDES, T. A.; SANTOS, E. C. Effect of biofertilization on yellow passion fruit production and fruit quality. Rev. Caatinga, v. 30, n. 1, p. 136148, 2017.

MORAES, M. T.; ARNUTI, F.; RODRIGUES DA S., V.; FERREIRA DA SILVA, R.; BASSO, C. J.; DA ROS, C. O. Dejetos líquidos de suínos como alternativa a adubação mineral na cultura do milho. Revista Semina: Ciências Agrárias, v. 35, n. 6, p. 2945-2954, 2014. 
NASCIMENTO, W. M. O.; TOMÉ, A. T.; OLIVEIRA, M. S. P.; MÜLLER, C. H.; CARVALHO, J. E. U. Seleção de progênies de maracujazeiro-amarelo (Passiflora edulis f. flavicarpa) quanto à qualidade de frutos. Revista Brasileira de Fruticultura, v.25, n.1, p. 186-188, 2003.

NETO, S. E.A.; SOUZA, S. R.; SALDANHA, C. S.; FONTINELE, Y.R.; NEGREIROS, M.; AZEVEDO, J. M. A.; OLIVEIRA, E. B. L. Produtividade e vigor do maracujazeiro-amarelo plantado em covas e plantio direto sob manejo orgânico. Ciência Rural, v. 39, n. 3, p. 678-683, 2009.

OLIVEIRA，F. I. F.; CAVALCANTE， L. F.; CAVALCANTE, I, B L.; SOUTO, A. G. L.; NETO, A. J. L. Crescimento e produção do maracujazeiro amarelo fertirrigado com esterco bovino líquido fermentado. Revista Agropecuária Técnica, v. 38, n. 4, p.191-199, 2017.

PEREIRA, S. E.; GONÇALVES, J. A. C.; VANIN, J. P.; STREY, L.; SCHWANTES, D.; NACKE, H. Aplicação de dejetos de suínos na cultura do milho cultivado em sistema de plantio direto. Acta Scientiarum Technology, v. 32, n. 2, 2010.

REIS, L. C.; FORESTI, A. C.; RODRIGUES, E. T. Desempenho de cultivares de maracujá (Passiflora edulis $f$. flavicarpa) no sistema de produção orgânico. Revista de la Facultad de Agronomía, v. 117 (2): 253-260 253, 2018.

RODOLFO JUNIOR, F.; CAVALCANTE, L. F.; BURITI, E. S. Crescimento e produção do Maracujazeiro-Amarelo em solo com biofertilizante e adubação mineral com NPK. Revista Caatinga, v. 21, n. 5, p.134-145, 2009.

RODRIGUES, A. C; CAVALCANTE, L. F.; DE OLIVEIRA, A. P.; DE SOUSA J. T.; MESQUITA, F. O. Produção e nutrição mineral do maracujazeiroamarelo em solo com biofertilizante supermagro e potássio. Revista Brasileira de Engenharia Agrícola e Ambiental, v.13, n.2, p.117-124, 2009.
SANTOS, G. D. Avaliação do maracujazeiroamarelo sob biofertilizantes aplicados ao solo na forma líquida. $74 p$. Dissertação Mestrado, Universidade Federal da Paraíba, Areia, 2016.

SBSC. Sociedade Brasileira de Ciência do Solo. Comissão de Química e Fertilidade do Solo. Manual de adubação e de calagem para os Estados do Rio Grande do Sul e de Santa Catarina / Sociedade Brasileira de Ciência do Solo. Comissão de Química e Fertilidade do Solo. - 10. ed. - Porto Alegre, 2004.

SCHERER, E. E.; NESI, C. N.; MASSOTTI, Z. Atributos químicos do solo influenciados por sucessivas aplicações de dejetos suínos em áreas agrícolas de Santa Catarina. Revista Brasileira de Ciência do Solo, v. 34, n. 4, 2010.

SILVA, T. L.; CAVALCANTE, I. H. L.; SOUSA, K. S. M.; GALHARDO, C . X.; SANTANA, E. A.; LIMA, D. D. Qualidade do maracujá amarelo fertirrigado com nitrogênio e substâncias húmicas. Comunicata Scientiae, v.6, n,4, p. 479487, 2015.

SINGH, G.; SEKHON, H. S.; SHARMA, P. Effect of irrigation and biofertilizer on water use, nodulation, growth and yield of chickpea (Cicer arietinum L.). Archives of Agronomy and Soil Science, v. 57, n. 7, p. 715-726, 2011.

SOUZA, J. A. R.; MOREIRA, D. A.; FERREIRA, P. A.; MATOS, A. T. Variação do nitrogênio e fósforo em solo fertirrigado com efluente do tratamento primário da água residuária da suinocultura. Revista Ambiente \& Água, v. 4, n. 3, p. 111-122, 2009.

TEJADA, M.; MORGADO, R. B.; GÓMEZA, I.; FRANCO, A. L.; BENÍTEZ, C.; PARRADO, J. Use of biofertilizers obtained from sewage sludges on maize yield. European Journal of Agronomy, v. 78, p. 13-19, 2016. 